\title{
Actin, Aortic Smooth Muscle
}

National Cancer Institute

\section{Source}

National Cancer Institute. Actin, Aortic Smooth Muscle. NCI Thesaurus. Code C103972.

Actin, aortic smooth muscle (377 aa, $42 \mathrm{kDa}$ ) is encoded by the human ACTA2 gene.

This protein plays a role in the contraction of smooth muscle. 